\title{
ENHANCING STUDENTS' READING ABILITY THROUGH PEER-ASSISTED LEARNING STRATEGIES (PALS)
}

\author{
Hasnani ${ }^{1}$, Agus Ismail ${ }^{2}$ \\ 1,2Universitas Megarezky \\ 1,2Antang Raya Street No. 43 Makassar \\ Email: hasnani.helmy@gmail.com ${ }^{1}$, agusismail@universitasmegarezky.ac.id ${ }^{2}$
}

\begin{abstract}
:
This study aims to enhance the students' reading ability through Peer-Assisted Learning Strategies (PALS) in SMA Negeri 19 Makassar. This research is a Classroom Action Research (CAR), which consists of four stages: planning, implementing, observing, and reflecting. The research techniques used are pretest, post-test, and observation. The findings showed that the use of Peer-Assisted Learning Strategies was successful in improving the students' reading ability. The improvement can be seen from the mean score of the students in cycle one is 23.1, which is categorized as good, while in cycle two, it is 73.1, which is classified as very good. Seventeen students met the Minimum Completeness Criteria (MCC) in cycle one, and 22 students completed the MCC in cycle two. Therefore, this research concludes that Peer-Assisted Learning strategies improve the students' learning outcomes of reading ability in SMA Negeri 19 Makassar.
\end{abstract}

\begin{abstract}
Abstrak:
Penelitian ini bertujuan untuk meningkatkan kemampuan membaca siswa melalui Peer-Assisted Learning Strategies (PALS) di SMA Negeri 19 Makassar. Penelitian ini merupakan Penelitian Tindakan Kelas (PTK) yang terdiri dari 4 tahap; perencanaan, pelaksanaan, observasi, dan refleksi. Teknik penelitian ini menggunakan tes dan wawancara. Hasil penelitian menunjukkan bahwa penggunaan Peer-Assisted Learning Strategies berhasil meningkatkan kemampuan membaca siswa SMA Negarei 19 Makassar. Peningkatan tersebut terlihat dari nilai rata-rata siswa pada siklus I sebesar 23,1 dengan kategori baik, dan pada siklus II sebesar 73,1 tergolong sangat baik. Tujuh belas siswa memenuhi Kriteria Ketuntasan Minimum (KKM) pada siklus satu, dan 22 siswa memenuhi KKM pada siklus dua. Oleh karena itu, penelitian ini menyimpulkan bahwa kemampuan membaca siswa meningkat melalui model pembelajaran Peer-Assisted Learning Strategies di SMA Negarei 19 Makassar.
\end{abstract}

\section{Keywords:}

Reading Ability, Learning Outcomes, Peer-Assisted Learning Strategies (PALS).

How to Cite: Hasnani \& Ismail, A. (2020). Enhancing Students' Reading Ability Through PeerAssisted Learning Strategies (PALS). Lentera Pendidikan : Jurnal Ilmu Tarbiyah dan Keguruan, 23(2), 260-270. https://doi.org/10.24252/lp.2020v23n2i6.

\section{INTRODUCTION}

"Reading is a window to the world" is a simple saying but has a profound meaning because, by reading, people can explore the whole world and vice versa. In 2019, the Program for International Student Assessment (PISA surveyed reading interest for school 
children aged 15 years in 79 countries, and Indonesia was ranked 74 out of 79 countries (PISA, 2019). Then in 2016, Central Connecticut State University (CCSU) conducted a study, "Most Littered Nation In The World" Indonesia was declared to be ranked 60th out of 61 countries regarding reading (Gewati, 2016).

Reading is a boring specter for school-age children. Books have been replaced by gadgets that they cannot remove, even though the Minister of Education previously required schools to read every day for 15 minutes (Alamsyah, 2015). The Makassar city government also has excellent attention to the Indonesians' reading interest, especially the Makassar people. On April 14, 2019, the Makassar city government gathered literacy activists through the Library Service to discuss strategies to foster reading interest among youth, especially in Makassar (Kamsah, 2019). This study is also a concern for researchers because of the low interest in reading for school-age children.

Ali bin Abi Talib said, "Whoever is entertained by books, happiness will not disappear from him"(Wahyudi, 2010). It is easy to find the path of happiness from reading, but not many people are aware of it. According to Tarigan, a task is a process carried out and used by readers to get messages, which the writer intends to convey through written language. Meanwhile, according to Sabarti Akhadiah that reading is an integrated set of activities that includes several activities such as recognizing letters and words, connecting them with sounds and their meanings, and drawing conclusions about the importance of the reading (Alkhaidah, 2002). Meanwhile, Wellings \& Edward said that task is a complex skill involving coordination of the language processing and eye movement systems. Forward movement of the eyes through text is primarily driven by the identification of words but modulated by other processes (Wellings \& Edwards, 2017).

According to Hedgcock \& Ferris, there are two types of readings, namely Intensive reading and Extensive reading. Hedgcock \& Ferris stated that intensive reading is a careful and deliberate examination of text for understanding. The goals beyond direct knowledge of a book include developing and practicing effective reading strategies, facilitating language development through reading, and building students' confidence in their $\mathrm{L} 2$ reading skills and motivation to read more and more broadly. The characteristics and benefits of intensive reading include the text to be studied selected by the teacher (possibly with input from students). While all students read the same book simultaneously and complete an exercise outside the classroom or the classroom designed or assigned by the teacher, the teacher highlights certain linguistic features and content dimensions of the text, introduces and reinforces selected reading strategies through whole-class teaching activities. The assessment of the students' understanding, reading development, and reading efficiency is facilitated by the fact that all students work concurrently with the same texts and activities (Hedgcock \& Ferris, 2009).

Hedgcock \& Ferris defines that extensive reading naturally exposes the reader to the occurring patterns of phrases and clauses, repeated and alternative uses of lexical items and spelling, and several other graphic features such as paragraphs, punctuation, and uppercase conventions. The benefits of extensive reading, such as: improving ability 
skills, developing automaticity, increasing background knowledge (schema, both content and format), building an understanding of vocabulary and grammar (e.g., language schemes), improving the productive skills (speaking and especially writing), and increasing self-confidence and motivation (Hedgcock \& Ferris, 2009).

Based on the reading benefits described above, the researchers support the Tarigan theory that task is a process carried out and used by the readers to get the message that the writer wants to convey through written language. By reading, the readers can find happiness and get many benefits, and they can expand knowledge and explore written statements in reading material. In addition, Scotter said that reading is a complex skill involving coordination of the language processing and eye movement systems. Forward movement of the eyes through text is mostly driven by the identification of words but modulated by other processes (Gage, Adamson, Macsuga, \& Lewis, 2016).

Several studies have been conducted previously related to reading skill using PeerAssisted Learning. Here are the details of the research that has been conducted, namely: 1) Using Peer-Assisted Learning Strategy on Reading Ability Of Analytical Exposition (Budiyanto, 2019), 2). Improving Students' Reading Ability Through Peer-Assisted Learning Strategy (PAL) (Nurkhairiyah, 2017), and 3) The Effects of Peer-Assisted Learning Strategies on High School Students with Serious Reading Problems (Fuchs \& Kazdan, 1999). Although several studies have been carried out in improving reading ability through the Peer-Assisted Learning Strategy (PAL), the researchers' research has differences in population and method aspects. Therefore, it is expected that the study conducted by the researchers can provide new insights for every element of education, especially for teachers and students of the middle age.

PALS is a whole-class peer-tutor program that addresses the various learning needs of each student. This cooperative learning technique integrates students and gives them the roles of "coaches" and "players" (Sáenz, Fuchs, \& Fuchs, 2005). Peer-Assisted Learning Strategies (PALS) is a peer-tutoring learning program that complements the primary reading curriculum (Fuchs, Mathes, \& Simmons, 1997). The pair of students work together in reading activities is intended to improve the reading accuracy, fluency, and ability. Paired students take turns taking the tutor and tutee's role who read aloud, listen to their partner's reading, and provide feedback during various structured activities (Fuchs, Mathes, \& Simmons, 1997).

The first step towards implementing the PALS strategy in the classroom is to get a baseline of all students' strengths and weaknesses. They are then ranked according to their skills and abilities (Spörer \& Brunstein, 2009). This information is used to form student pairs carefully - the students with higher achievement/skill rank are paired with the students with low or average scores. The installation is done to encourage the students to learn from each other through teaching and practice (Fuchs \& Kazdan, 1999).

Following the principle of Reciprocal Teaching, each student takes turns being a Coach and a Player (Sung, Chang, \& Huang, 2008). Coaches are instructed to observe, assist, and provide constructive feedback to the Players and they are even equipped with 
guidance to follow. The pairs are regularly shuffled to allow the students to learn and interact with others (McMaster, Fuchs, \& Fuchs, 2006). The PALS technique is usually a 25-35 minute activity performed at least 2-4 times a week. This technique allows students to participate in various activities. Therefore, it enables the teacher to observe, supervise, and provide individual intervention when needed (Fuchs \& Kazdan, 1999). Several steps can improve the students' reading ability, namely Read Partners: the peer reads the passage aloud as the players follow. The role is activated, and then the section is reread. Depreciation of Paragraphs: the students are instructed to read aloud and then summarize and state the main ideas from the passage. This method encourages them to show their understanding of the path. Prediction Relay: one pair tries to predict the possible information in the next part of the text and then reads from that part to find the data. The researchers regard that Peer-assisted Learning Strategies is the best solution to improve the students' reading ability.

\section{RESEARCH METHOD}

Classroom Action Research (CAR) is a study conducted by teachers (educators) in a classroom or where they teach that focuses on improving the learning process and praxis (Kasinah, 2013). CAR's primary purpose of strengthening learning practices on an ongoing basis and each cycle includes planning (plan), action, observation, and reflection (Arikunto, 2006). When school conditions were not conducive to conducting conventional research, the researchers conducted blended-learning research using educational applications. This research was conducted online.

The researchers conducted Peer-Assisted Learning Strategies that consists of two learning models: face-to-face learning and online learning. The use of Peer-Assisted Learning Strategies can stimulate the students' motivation to study. The theory supported it drew (2008) with Peer-Assisted Learning Strategies, and the teachers can use the learning resources available online and in face-to-face learning to attract the students' attention and help them become more active and effective learners. This research took place at SMA Negeri 19 Makassar. The study was conducted from July to September 2020. The subjects of this study were the students of class 2 SMA Negeri 19 Makassar, with 26 students. The research subjects consisted of 10 male and 16 female.

The data collection techniques used in this study were pretest, post-test and observation. The data about the teachers' and students' activities in the teaching and learning process were taken using words directly and indirectly with several observed indicators. The procedure carried out in this cycle for implementing the actions in this cycle can be described as follows: Planning Stage, developing a semester learning plan by the learning material to be taught, compiling and building the learning plans. The teacher made an instrument of observation guidelines to observe in the classroom during the learning process, and made the final test instruments for cycles I and II to determine the students' learning outcomes after the self-peer-assessment method is applied in the teaching and learning process. 
Furthermore, in the action of Implementation Stage, the teacher wrote down the material to be studied, explained the learning objectives to be achieved, discussed the the material, divided the students into pairs, and the teacher and the researchers delivered material to each group taking action according to their role. The teacher became a facilitator during the learning process using the Peer-Assisted Learning Strategy. At this stage, there were two treatments, namely observation and evaluation. The implementation of the observation stage on the students' activities and teaching activities in the teaching and learning process used observation sheets. At this stage, the pretest was also carried out to see the students' initial abilities. The evaluation's implementation provided a learning outcome test was carried out at the end of each cycle's action to know the increase in the students' learning outcomes.

The researcher reflected the results achieved in the observation and evaluation stage collected and then analyzed and reflected at this stage. The reflection is intended to see whether the plan has been implemented optimally or needs improvement. The analysis results of cycle one were used as the reference to the next process of cycle two. The aspects that were considered acceptable are maintained. In contrast, the shortcomings were considered and revised in the next cycle. The test in the form of retelling the stories was used to retrieve the data on each cycle to get the data about the students' learning outcomes after implementing Peer-Assisted Learning Strategies in the teaching and learning processes.

The students' learning outcomes data in the form of tests were analyzed using the same score based on the benchmark reference assessment or Maximum Completion Criteria (MCC) at SMA Negeri 19 Makassar. the completeness is calculated based on the maximum score achieved by the students.

\section{RESULTS AND DISCUSSION}

This classroom action research was conducted at SMA Negeri 19 Makassar. Class 2 social studies was the research subject in implementing classroom action research (CAR) in improving the students' reading skills in English. The research subjects were 26 students consisting of 10 males and 16 females. This research was conducted in 2 cycles, and each cycle consisted of three meetings. Each cycle was subjected to the test or evaluation at the end of the cycle. The study results were in the form of exposure to the data obtained from each cycle in implementing peer-assisted learning strategies in English language learning for class II IPS students at SMA Negeri 19 Makassar.

\section{Problem Identification}

Before implementing Peer-Assisted Learning Strategies in the school, the researchers first compiled the planning stages of the teaching and learning process at SMA Negeri 19 Makassar. Before taking the action, the researchers observed and identified the problems of the XI IPS class students of SMA Negeri 19 Makassar for the academic year 2020/2021. Furthermore, the researchers continued the observation by interviewing several classes XI IPS 2 students and their English teacher. 
Based on the observations in class XI IPS at SMA Negeri 19 Makassar, the researchers found many problems related to the students' reading comprehension. The questions are presented in the table below:

Table 1: The Questions are Presented

\begin{tabular}{clc}
\hline No & \multicolumn{1}{c}{ Problems } & Note \\
\hline 1 & Students think that English a problematic subject & $\mathrm{S}$ \\
\hline 2 & Lack of students motivation in learning & $\mathrm{S}$ \\
\hline 3 & Students are bored with English learning activities & $\mathrm{S}$ \\
\hline 4 & The low vocabulary of students & $\mathrm{S}$ \\
\hline 5 & Students have difficulty finding the main idea in a reading & $\mathrm{S}$ \\
\hline 6 & Students do not realize the usefulness of an efficient reading strategy & $\mathrm{S}$ \\
\hline 7 & Teacher-centered learning & $\mathrm{T}$ \\
\hline 8 & There is no feedback from the teacher & $\mathrm{T}$ \\
\hline 9 & The less varied learning method & $\mathrm{M}$ \\
\hline & T: Teachers S: Student &
\end{tabular}

The problem indicators came from internal and external factors. The internal factors were caused by the students, and the external factors were caused by the teacher techniques during the teaching and learning process. Because the researchers only focused on the students' reading comprehension, the researcher selected several problems that would have implications on the teaching and learning.

Reflection of cycle one was carried out to review and reflect on the planning and implementation process, which was considered less fully implemented and should be further improved in the learning process. The implementation of reflection in cycle one aimed to look back at the learning process carried out in both the teacher teaching activities and the students' learning activities based on the learning stages using PeerAssisted Learning Strategies (PALS). From the post-test results in cycle I, the students 'scores had not reached the completeness value, and the students' reading comprehension had not been fulfilled, so the researchers continued the research to the second cycle.

The implementation of reflection in cycle II refered to the teaching activities and learning activities that had been carried out based on pairs in English lessons, various improvements made by the teacher. Based on the analysis and reflection of cycle II, it can be concluded that English learning had been categorized as successful. Thus the learning objectives that had been set had been achieved. The Peer-Assisted Learning Strategies had been proven to have improved the students' learning outcomes and developed the students' creativity, both individually and in pairs. From the post-test results in the second cycle, the students experienced an increase in reading comprehension, so that the researchers did not continue the research to the next cycle.

The results of the two-cycle of Peer-Assisted Learning Strategies show that peerto-peer learning can enhance the students' reading comprehension skills of school-aged students. Based on the PALS model's implementation, the learning outcomes of cycle one 
show that the mean score of the students' learning outcomes can be assumed to be in an appropriate group.

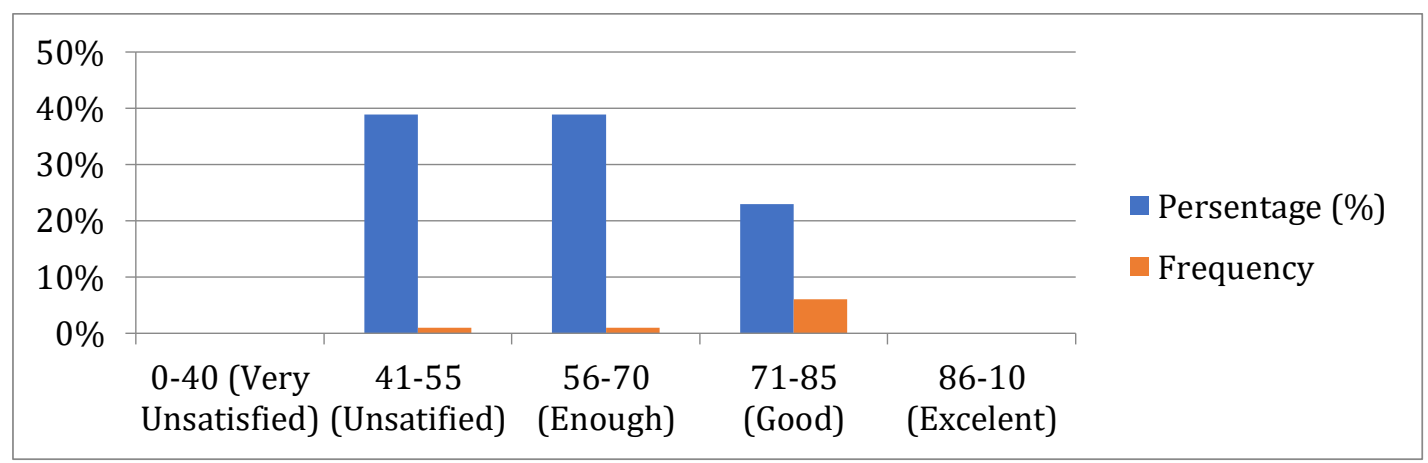

Figure 1. Frequency and Percentage Distribution Bar Charts Cycle One of the Students' Learning Outcomes

Based on the table and diagram above, it is recognized that there are no students with awful and excellent grades. There are 10 students (38.9 per cent), 10 students (38.9 per cent) and 6 students (23.1). therefore, It can be said that the average learning outcomes of the 11 students of SMA Negeri 19 Makassar are in the category of low and sufficient in Cycle I.

Table 2. The Students' Completion of Cycle I Learning

\begin{tabular}{llll}
\hline Score & Category & Frequency & Percentage (\%) \\
$0-69$ & Incomplete & 20 & $76.9 \%$ \\
\hline $70-100$ & Complete & 6 & $23.1 \%$ \\
\hline & Jumlah & $\mathbf{2 6}$ & $\mathbf{1 0 0}$ \\
\hline
\end{tabular}

Table's completeness learning outcomes show that 20 students who gain scores 0 69 with the percentage of $76.9 \%$ are in incomplete category. At the same time, six students who gain scores $70-100$ with the percentage of $23.1 \%$ are in complete category. As a result, the teacher offers students instructions to properly prepare themselves for the learning process; more action is being taken, namely in Cycle II. The students' scores have improved in Cycle II. The data on learning outcomes were collected during the second cycle of action by assessing the students. Based on the findings of the Cycle II assessment of the students' learning activities, the following data were obtained.

Table 3. Frequency distribution and percentage of students' learning outcomes in Cycle

\begin{tabular}{llll}
\hline \multicolumn{1}{c}{ Interval Value } & Frequency (f) & Percentage (\%) & Category \\
& & & \\
\hline $0-40$ & 0 & 0 & Very Unsatisfied \\
\hline $41-55$ & 2 & 7.7 & Unsatisfied \\
\hline $56-70$ & 5 & 19.2 & Enough \\
\hline $71-85$ & 15 & 57.7 & Good \\
\hline
\end{tabular}




\begin{tabular}{llll}
\hline $86-100$ & 4 & 15.4 & Very Good \\
\hline Total & $\mathbf{2 6}$ & $\mathbf{1 0 0 \%}$ &
\end{tabular}

Based on the tables and diagrams, it is understood that there are no students with very low grades, two students are in the unsatisfied category (7.7\%), five students are in the excellent type (19.2\%), fifteen students are in a good variety (57.7\%), and four students are in the excellent category (15.4\%). There is an improvement in the mean score of the students' learning outcomes after the second cycle, namely 81.41, which has met the Minimum Completeness Criteria (MCC) of 70.

Table 4. The Students' Completion in Cycle II

\begin{tabular}{llll}
\hline Skor & Category & Frequency & Percentage (\%) \\
\hline $0-69$ & Incomplete & 7 & $26.9 \%$ \\
\hline $70-100$ & Complete & 19 & $73.1 \%$ \\
\hline & Total & $\mathbf{2 6}$ & $\mathbf{1 0 0}$ \\
\hline
\end{tabular}

Based on the table above, the learning outcomes' completeness shows that seven students who gain scores 0-69 with the percentage of $26.9 \%$ are in incomplete category, and nineteen students who gain scores $70-100$ with the percentage of $73.1 \%$ are in complete category. Therefore, the implementation of PALS learning model in English lessons has increased, particularly in the students' ability to read.

Based on the explanation and the percentage above, the Cycle I and Cycle II test results improved the English learning outcomes. It indicates that the students' learning outcomes in Cycle I (completeness) are 62.50 percent with adequate qualifications and the students' learning outcomes in Cycle II (fullness) are 96.87 percent with excellent qualifications. Therefore, in this second cycle, the researchers stopped the study because the target has been achieved. It means that the application of the self-assessment and peer assessment models to the English learning has been successful.

Based on the evidence provided in the study's findings, the topic focuses on teaching practices and students' practices in the application of peer-reviewed learning methods. In peer-reviewed learning strategies, the researchers first asked SMA Negeri 19 Makassar students of the second grade to record their reading of English stories and then sent them to their peers for evaluation. The two of these students provided an appraisal, and the same activity was also done by the partner. The researchers then produced recordings of stories to be used for self-assessment. This paper aims to review pronunciation and speech fluency. In particular, the researchers intended to encourage them to challenge themselves to discover the mistakes they made in their pronunciation, familiarize themselves with English expressions, not dialed English vernacular, and learn from such patterns what structures are valid valuable.

Partner assessments are usually sharp and otherwise honest. It is not unusual for researchers to point out unnoticed errors in the student work. However, some students also distrusted the peer review by asking the researchers to affirm that their peer evaluation was correct. It may suggest that the researchers still have some ways to lead 
them to take full responsibility for assessing the quality of what they learn. Selfassessment is more successful than input from the teacher. Pair assessment typically refers to the students' evaluation of all aspects, including vocabulary, grammar, originality, style, structure, and so forth.

The usa of peer evaluation: while all students can quickly understand the evaluation of expertise, the assessment process appears fresh. The method evaluation refers to an assessment that starts with assessing the efficacy of each phase of the operation. The researchers use several tasks: read short stories, read quickly, and look for ideas. In addition, the researchers take advantage of resources that can inspire the students to use all of the vocabularies to produce successful results, such as small-group problem-based activities, photo storytelling, guessing games, group conversations, peerto-peer instruction, and so forth. The researchers should constructively inspire the research students. The participation is in research groups, group presentations on context knowledge related to text, for example. The grades that the students put on themselves are usually higher than what the researchers expect.

In individual sections, the learning methods of the students have shifted. When searching for knowledge on documents, debating material in groups, it is clear that the students have an active exchange of ideas, try to use deep learning, create more effective and motivating research ideas.

Based on the research that has been conducted, the resulting research has improved by using peer-assisted learning strategies. Many aspects have improved, namely vocabulary, the enthusiasm of study, and reading ability in English. The students' English learning outcomes from both research periods have increased before the predetermined performance indicators have been reached, that indicate that the students' English learning outcomes have increased significantly. Peer-assisted learning interventions to enhance the students' learning outcomes that are initially poor can be increased by following the PALS-based English learning.

\section{CONCLUSION}

Following the implementation of peer-assisted learning methods, this study concludes that the researchers found out that the students' reading ability improved by using peer-assisted learning strategies. The students were more excited about studying; they were more attractive during the English teaching and learning activities.

The next researchers' recommendation to improve students' English mastery can be accomplished using peer-reviewed learning methods. This analysis presents several positive and negative elements that the other researchers may use as a new perspective or information. The researchers also expects that this study can be a source for other researchers in the teaching and learning process. 


\section{REFERENCES}

Alamsyah, I. E. (2015). Mendikbud: Siswa Wajib Baca Buku 15 Menit Sebelum Belajar. Republika.

Alkhaidah. (2002). Pembinaan kemampuan menulis bahasa indonesia. Pembinaan Kemampuan Menulis Bahasa Indonesia.

Arikunto, S. (2006). Prosedur Penelitian Tindakan Kelas. Jakarta: Bumi Aksara.

Budiyanto, D. (2019). Using Peer Assisted Learning Strategy On Reading Comprehension Of Analytical Exposition. Jurnal Ilmiah Bina Edukasi. https://doi.org/10.33557/jedukasi.v12i01.483.

Damarjati, D. (2019). Benarkah Minat Baca Orang Indonesia Serendah Ini? Detik.

Fuchs, D., Fuchs, L. S., Mathes, P. G., \& Simmons, D. C. (1997). Peer-Assisted Learning Strategies: Making Classrooms More Responsive to Diversity Peer-Assisted Learning Strategies Melting Pot Versus Cultural Pluralism. American Educational Research Journal Spring. https://doi.org/https://doi.org/10.2307/1163346.

Fuchs, L. S., Fuchs, D., \& Kazdan, S. (1999). Effects of peer-assisted learning strategies on high school students with serious reading problems. Remedial and Special Education. https://doi.org/10.1177/074193259902000507.

Gage, N. A., Adamson, R., Macsuga-gage, A. S., Lewis, T. J., Mayworm, A. M., Sharkey, J. D., Hunnicutt, K. L., Schiedel, K. C., Santoro, A. F., Ingraham, C. L., Hokoda, A., Moehlenbruck, D., Karafin, M., Manzo, C., Ramirez, D., Gregory, A., Clawson, K., Davis, A., Gerewitz, J., ... Achilles, C. M. (2016). Advanced Preparation Standards. Implementation Science. https://doi.org/10.1002/pits.

Gewati, M. (2016). Minat Baca Indonesia Ada di Urutan ke-60 Dunia Artikel ini telah tayang di Kompas.com dengan judul "Minat Baca Indonesia Ada di Urutan ke-60 Dunia", https://edukasi.kompas.com/read/2016/08/29/07175131/minat.baca.indonesia.a dadi.urutan.ke-60.dunia. Kompas.

Hedgcock, J. S., \& Ferris, D. R. (2009). Teaching readers of English students, texts, and contexts. In Teaching Readers of English Students, Texts, and Contexts. https://doi.org/10.4324/9780203880265.

Kamsah. (2019). Sikapi Rendahnya Minat Baca Warga Makassar, Dinas Perpustakaan Kumpulkan Pegiat Literasi.

Kasinah, S. (2013). Classroom Action Research. Pionir. https://doi.org/10.17977/um099v1i12017p36.

McMaster, K. L., Fuchs, D., \& Fuchs, L. S. (2006). Research on peer-assisted learning strategies: The promise and limitations of peer-mediated instruction. Reading and Writing Quarterly. https://doi.org/10.1080/10573560500203491.

Nurkhairiyah, N. (2017). Improving Students' Reading Comprehension through PeerAssisted Learning Strategy (PALS) at Grade XI. C of MA Pondok Pesantren Daarun Nahdhah Thawalib Bangkinang (PPDN-TB). J-SHMIC: Journal of English for Academic. https://doi.org/10.25299/jshmic.2017.vol4(1).509.

Sáenz, L. M., Fuchs, L. S., \& Fuchs, D. (2005). Peer-assisted learning strategies for english language learners with learning disabilities. In Exceptional Children. https://doi.org/10.1177/001440290507100302.

Spörer, N., \& Brunstein, J. C. (2009). Fostering the reading comprehension of secondary 
school students through peer-assisted learning: Effects on strategy knowledge, strategy use, and task performance. Contemporary Educational Psychology. https://doi.org/10.1016/j.cedpsych.2009.06.004.

Sung, Y. T., Chang, K. E., \& Huang, J. S. (2008). Improving children's reading comprehension and use of strategies through computer-based strategy training. Computers in Human Behavior. https://doi.org/10.1016/j.chb.2007.05.009.

Wahyudi. (2010). Membaca Sebagai Suatu Keterampilan Berbahasa. Visi Ilmu Pendidikan. http://library.um.ac.id/free-contents/index.php/buku/detail/membaca-sebagaisuatu-keterampilan-berbahasa-oleh-henry-guntur-tarigan-20285.html.

Wellings, A., \& Edwards, V. (2017). Reading. In English 7 - 14 (1991): Every Child's Entitlement. https://doi.org/10.4324/9781315146553. 